\title{
11 Destination Brands Dubai and Abu Dhabi: Bitter Rivalry or Strategic Partnership?
}

\author{
Laura J. Lawton and David B. Weaver
}

\section{Introduction}

Statements about the impressive growth of tourism in the Arab world, made throughout this book, are misleading if they are not qualified by statements about the sector's highly skewed geographical distribution. Several destination-cities, notably Dubai but also Abu Dhabi, Doha and Bahrain, have status as hyper-concentrated and rapidly growing nodes of tourismrelated activity surrounded beyond their immediate semi-developed hinterlands by enormous tracts where tourism is negligible due to harsh geophysical environments, isolation and/or socio-political instability. Centripetal tendencies in the former that foster ever-higher levels of tourism development contrast with centrifugal tendencies in the latter which discourage diffusion, resulting in amplified 'oasis effects'. More broadly, this embodies the idea of a 'Middle East tourism paradox' wherein these oases are seen to thrive within an overall regional context of ethnic and religious rivalry and geopolitical tension (Hazbun, 2006). With the direct economic benefits generated by and accruing to such a small portion of the Arab landscape, the question of how these privileged oases emerge and remain as such is a worthy topic of investigation that has already received considerable attention (Ali, 2010; Balakrishnan, 2008; Elsheshtawy, 2010; Henderson, 2007; Steiner, 2010).

Also worthy but far less interrogated, however, is the question of regional rivalry and interaction among these oases. This chapter begins by focusing on the development of Dubai as the regional tourism hub or 'primary oasis'. It subsequently proposes a $6 \mathrm{~S}$ branding model which accounts for and characterises this primacy but also accommodates consideration of the threats to same. A 'brand' is an important concept because it identifies a product or organisation and serves as a basis for positive recognition and differentiation 
from competitors. Capturing unique characteristics and core values, a wellarticulated and disseminated brand identity reduces the likelihood of substitutability (Keller, 1993; Morgan et al., 2002). Positive brand awareness and image, as such, serves to stimulate purchase and foster loyalty among consumers hoping to derive satisfaction and other benefits from exposure to and participation in the attendant brand proposition. Destination branding is distinctive because of the complex and multi-faceted character of places, which includes the incorporation of competing hotel and attraction subbrands, and the presence of multiple stakeholders, some of whom (e.g. the military or mining interests) may not have any vested interest in supporting the 'destination' aspect of that place even though paradoxically they may contribute substantively to brand character. Our own $6 \mathrm{~S}$ distillation of 'Brand Dubai', based on an analysis of the secondary literature, may help tourism stakeholders in Dubai to articulate their formal destination brand as basis for consolidating and strengthening its competitiveness as a destination. Informed partly by this Dubai model, the emergence of Abu Dhabi as a sister oasis - and potential competitor as well as collaborator - is then discussed, and a modified 6S Abu Dhabi destination brand proposed. Indeed, Bagaeen's (2007) description of Abu Dhabi, Doha (Qatar) and Bahrain as 'following in Dubai's footsteps' (p. 184) discloses emulation but could also be taken variably as evidence of competition or collaboration. A basic question is whether Dubai will persist as The Global Arab City or evolve as just one of several Global Arab Cities? The chapter concludes by identifying the broader patterns and implications that arise from this dual case study.

\section{Rise of Destination Brand Dubai}

Prior to the 1960s, the Trucial State of Dubai was a relatively obscure Middle Eastern backwater noted mainly for its trade with nearby Iran and its feuds with the neighbouring Trucial State of Abu Dhabi (Stephenson \& Ali-Knight, 2010). The first hotel was not opened until 1959 and the first airport just a few years prior to that. The discovery of oil in the 1960s was a major catalyst for change, generating revenue surpluses that allowed a succession of enlightened Sheikhs to invest in modernisation and diversification of the economy through what Kim and Mauborgne (2009) describe as a reconstructionist 'blue ocean' strategy. By the early 2000s, Dubai was established as a major node of tourism activity within the Arab world and Middle East, and a very successful example of destination branding (Balakrishnan, 2008). Destination branding involves the formation of primary and secondary images that instigate positive associations (e.g. differentiation, assurance of quality, reliability) and behaviour (e.g. positive word-of-mouth promotion, repeat visitation) among actual and potential visitors, thereby improving competitiveness (Blain et al., 2005). Notably, these images can be either 
induced, that is, generated deliberately by destination marketers to strengthen and promote the brand, or organic - emerging spontaneously and with positive or negative impacts through the effects of word of mouth (WOM), social media (eWOM) or conventional media (Fakeye \& Crompton, 1991). As follows, we describe this dominant Brand Dubai (Elsheshtawy, 2010) as a synthesis entailing the approximately sequential interrelated qualities of being stable, strategic, superlative, sophisticated, sustainable and successful.

\section{Stable}

The dark side of the Middle East tourism paradox presents as a seemingly relentless panorama of present danger and imminent conflict, highlighted by a succession of Arab-Israel wars, the invasions of Kuwait and Iraq, and several Lebanese sectarian conflicts. At the time of writing, the extremist 'Islamic State' was maintaining de facto control over much of Syria and Iraq while a deepening civil war in Yemen presented itself, increasingly, as a proxy for the growing regional rivalry between Sunni Saudi Arabia and Shi'ite Iran. Serving as a stark counter-narrative is the stability of Dubai, regarded widely as both safe and secure for tourists and other visitors. Indeed, Hazbun (2006) contends that escalations of regional conflict tend to be matched in Dubai, as if in defiance, by equivalent escalations of investment and construction. Typically, enclave spaces are utilised to insulate tourism sites from the threat of terrorist attacks, while long-standing strategies of market diversification have reduced dependency on segments less likely to visit in the event of a terrorist attack or looming conflict. In 2013, Europe and the Americas collectively accounted for $44 \%$ of total hotel visitor-nights, while $6 \%$ were generated from within the UAE, 23\% from the Arab Gulf Countries Council (AGCC) and other Arab countries, and 24\% from other parts of Asia and Africa (Government of Dubai, 2015). Resultant robust visitation growth in the wake of the 9/11 attacks in 2001 reinforced this image of stability, which can be regarded as a 'precursor variable' that enables other dimensions of the brand to crystallise. A serious apparent threat, however, is the growing regional rivalry between Saudi Arabia and Iran, given Dubai's vulnerable buffer zone location and 'natural' affiliations with its Sunnidominated Saudi neighbour (Wehrey et al., 2009).

\section{Strategic}

A paradox within the Middle East tourism paradox is that the region has always been inherently attractive, regardless of its instability, because of its strategic location at the crossroads of Asia, Europe and Africa. One conspicuous indication of this global centrality is the development of Dubai International Airport as a major transit hub, handling in 2015 more than 78 million passengers, 2.5 million tonnes of cargo, and 403,500 aircraft 
movements (Dubai Airports, 2015). A lucrative revenue source in its own right, this transit activity, accounting for about one-half of the traffic (Murel \& O'Connell, 2011), is also used to disseminate Brand Dubai to stopovers through attractions and promotions within its several terminals and through the good reputation of the Dubai flag carrier, Emirates airline. This indicates a 'quasi-destination' function that seeks to convert transit passengers into future stayover visitors, a strategy evident also in Singapore's Changi International Airport (Tang, 2015). Also capitalising on strategic location is a flourishing business and MICE (meetings, incentives, conventions and exhibitions) sector (Henderson, 2007) and iconic sites such as The World real estate development that from the air resembles a map of the world.

\section{Superlative}

Perhaps the most distinctive and publicly projected element of Dubai's destination brand is the growing inventory of superlative structures and capacities (Elsheshtawy, 2010). The term 'superlative' indicates absolute excellence within a global context. Thus, the Burj Khalifa is the world's tallest building while the Burj Al Arab is the world's first seven-star hotel and an emerging destination icon because of its unique traditional sailboat (dhow)-inspired design (Hazbun, 2006). Overall, an impressive $70 \%$ of Dubai's accommodation capacity is represented by five-star (41\%) and four-star (29\%) hotels (Government of Dubai, 2015). The Palm and The World real estate developments are also instantly recognisable and also emerging icons within the broader destination brand, becoming major induced tourist attractions in their own right. Dubai also endeavours to become the first 'logistics city' (Bagaeen, 2007) while its airport is touted as having the world's largest terminal and highest passenger volume (Dubai Airport, 2015). Steiner (2010) contextualises many of these superlatives as evidence of a 'hyper-reality' of heritage-imitative or self-referential symbolic capital that may ultimately become its own frame of reference for other imitators. This allows Dubai to create its own hybridised sense of place that does not offend any particular market segment. However, while intended to attract sustained admiration, there is a danger that superlatives will give way to perceptions of excess and vulgarity, based as some are on hubris and political legitimisation more than pragmatism. An associated danger is ephemerality, wherein today's number one can quickly become tomorrow's number two that attracts no one's interest.

\section{Sophisticated}

The complex quality of sophistication captures affiliated dimensions such as cosmopolitanism, diversity, tolerance, modernity, innovation and openness that speak of a confidant and accepting global city. All these traits 
are featured as themes in Dubai's upcoming hosting of Expo 2020 (Expo $2020,2016)$. Manifestations at a more mundane level include tolerance for the consumption of alcohol, excellent internet connectivity, and the widespread availability of luxury global brands. The latter reflects what Stephenson and Ali-Knight (2010) describe as 'massclusivity', that is, a lucrative and innovative high-volume/high-yield tourism product that challenges usual high end tourism assumptions of low volume/high yield. Such brand sophistication contrasts with and represents a potential threat to the traditional local conservative Salafi Islamic culture, but is accommodated in part through strict spatial demarcations redolent of MacCannell's (1976) backstage/frontstage distinctions. Expatriates, accordingly, can purchase land within selected 'free zone' locations, while tourists can consume alcohol and wear short clothing in their enclave hotels, heeding gentle public reminders to otherwise dress modestly and respect local customs (Visit Dubai, 2015). Nevertheless, accusations of excessive liberality are made frequently in some quarters, and of excessive constraint and intolerance in others (Stephenson, 2014), indicating the challenges inherent in negotiating between cultural extremes.

\section{Sustainable}

Sustainability is the most recent and least crystallised element in the Brand Dubai portfolio, as well as the most challenging given widely accepted but confounding and possibly naïve 'Triple Bottom Line' assumptions about addressing economic, environmental and socio-cultural impacts simultaneously. Efforts to project an image of cutting edge sustainability engagement include events such as the UNEP-sponsored First Dubai International Forum on Sustainable Lifestyles held in February 2015, and the announcement of the Middle East Centre for Sustainable Development, which arose from the Dubai Strategic Plan 2015 and advocates LEED certification for new construction, including hotels and theme parks (MECSD, 2015). Sustainability is also featured as an additional Expo 2020 theme. It is difficult, however, to reconcile such initiatives with local indicators that appear unsustainable. These feature a growth in resident population from 180,000 in 1975 to 690,000 in 1995, 1.3 million in 2005, and over 2.1 million in 2014, with concomitant increased demand for and consumption of fresh water, fossil fuels and other resources. Associated environmental degradation includes damaged coral reefs, oyster beds and seagrass fields caused by constructioninduced siltation (Bagaeen, 2007).

A parallel socio-cultural indicator of concern is that Arab UAE citizens now account for just $10-15 \%$ of the resident population, and accusations of expatriate labour exploitation are commonly made. Preservation of local cultural heritage is also limited, with the establishment of small restored historical districts serving mainly (and unintentionally) to amplify the 
aforementioned culturally decontextualised hyper-realities (Stephenson, 2014). Economically, it is contended that Dubai survived the GFC only because its 'reckless' development sector enjoyed a financial bailout from Abu Dhabi (Bloch, 2010). It is because of such significant economic, ecologi$\mathrm{cal}$ and sociocultural concerns that Dubai is characterised by some as 'a striking example of flawed sustainability' (Bassens, 2010: 300), although one that as yet has not seriously damaged the underlying destination brand.

\section{Successful}

The culminating Brand Dubai quality is success, predicated on widespread (though not universal) acceptance of the destination as simultaneously stable, strategic, superlative, sophisticated and sustainable. Success is evidenced by both performance and recognition. Tourism, for example, has increased from 5 million international stayover arrivals per year in the early 2000 s to 11 million in 2013 (or 29 million hotel visitor-nights), with anticipation of 20 million in 2020 (Dubai Tourism, 2015). As such Hazbun (2006) describes Dubai as 'the most stunning example of the so-called Middle East tourism paradox' (p. 208). Associated accolades include being named the IFEA World Festival and Event City in 2012 by the International Festivals and Events Association (cities $>1$ million category), and World Travel Awards for 'World's Leading Destination' in 2004, 2008, 2013 and 2014. Successful performance and recognition extend to complementary non-tourism Brand Dubai dimensions such as global finance, high tech, and medicine. Beyond its inherent merit, success is desirable because it can spawn a self-reinforcing 'virtuous spiral' of further success (Lawler, 2005) by attracting investment and high quality human resources.

\section{Abu Dhabi}

The discussion of tourism rivalry (or lack thereof) between Dubai and Abu Dhabi requires a brief overall context. Superficial physical resemblances and spatial proximity foster widespread perceptions of cultural and geographical uniformity, especially in the West. However, different ruling families and disparate resource endowments have dictated divergent paths of development, even paradoxically since the two emirates joined with four others in 1971 to form the United Arab Emirates. Davidson (2007) contends that Dubai has had a long history of relative openness and mercantilism, and that it was this historical legacy, rather than some contemporary impulsiveness to internationalise, that underlies the current contours of Brand Dubai. Abu Dhabi, in contrast, maintained a more insular attitude, resulting in and reinforced by the migration of many of its more entrepreneurially ambitious residents to Dubai. Historically, most of its enormous post-1950s oil revenue 
(controlling as it does about $95 \%$ of UAE oil reserves) has accrued as a sovereign wealth fund rumoured to be in excess of $\$ 300$ billion (Sambidge, 2012). Negligible amounts, by comparison, were allocated to local infrastructural development, education, or other capacity-building initiatives, and there was little need to make any decisions entailing risk or innovation (Abdelal, 2009).

Although the rulers of Abu Dhabi continue to invest a substantial portion of their wealth beyond the emirate, post 1971 governments have been increasingly cognisant of the need to build local capacity and encourage economic diversification in anticipation of depleted oil reserves. This imperative for diversification is recognised in the landmark Abu Dhabi Economic Vision 2030 (Abu Dhabi, 2008). Unlike Dubai, much of this investment initially occurred as heavy industrial development and only more recently has manifested as grandiose 'signature' projects linked to tourism. It is in the latter rather than the former that indications of rivalry might be expected, but these are not really to be found. Rather, Abu Dhabi subsidises Dubai by paying most of the costs for defence, diplomacy and other activities vested in the federal government, allowing its sister emirate to focus on its much broader portfolio of economic diversification (Kim \& Mauborgne, 2009). Most notably, Abu Dhabi used its vast oil wealth to bail out Dubai World, the emirate's largest development agency, with $\$ 10$ billion during the Global Financial Crisis (Bassens, 2010). This restored the credibility of Dubai by directly and forcefully reinforcing the 'stability' and 'success' dimensions of its destination brand. The benefits are reciprocal in that Dubai does not challenge the political dominance of Abu Dhabi within the federation or the authoritarian rule of its governing family, makes substantial contributions to its economic wealth and diversification, and creates high-end jobs for residents of the other emirates (Davidson, 2007). Essentially, the federal system confers great autonomy on Dubai but allows it to call upon the resources of Abu Dhabi to ensure that its brand integrity is maintained and strengthened. Bassens (2010) describes how the UAE is characterised by cycles of urban competition-decentralisation and urban cooperation-centralisation, with a flexible Dubai emphasising the former when it is booming and the latter when it is in trouble.

\section{Emerging destination brand Abu Dhabi}

Within the context of this oscillating symbiosis it appears that Abu Dhabi wishes neither to imitate nor undermine its neighbouring emirate, including in its emergent tourism policies and destination brand (Bloch, 2010). These can similarly be interrogated within the $6 \mathrm{~S}$ model employed above for Dubai, though in a different sequence for logical consistency. Beginning with sophistication, Abu Dhabi (like Dubai) aspires to create an inventory of 'world class' attractions as part of its indigenous economic diversification strategy. However, these attractions, in keeping with the emirate's 
conservative dispositions (Abu Dhabi, 2008), evoke the traditional more than the modern (though incorporating both), and the cultural more than the contrived (Sharpley, 2002; Stephenson \& Ali-Knight, 2014). Emblematic is the Sheikh Zayed Grand Mosque, a 12 -hectare US $\$ 545$ million structure capable of accommodating more than 7000 worshippers in its main prayer hall (World eBook Library, 2015). Maintaining the tradition/culture combination but seeking greater appeal to Western audiences is a Guggenheim Museum and a branch of the Louvre, both under construction at the time of writing. Evincing great quality but focusing on culture and heritage, we suggest that Abu Dhabi's emerging destination brand is selectively sophisticated with both indigenous and international dimensions.

The superlative amalgamates with and reinforces the sophistication dimension. The pending Guggenheim Abu Dhabi, for example, is promoted as the world's biggest Guggenheim museum, and the Grand Mosque as the most expensive and with the largest carpet. Similar to Dubai, $66 \%$ of all accommodation is denominated at the five-star or four-star level (Skift, 2015). Notably, there is no apparent intent to usurp Dubai's Burj Khalifa by erecting a taller building. In general, such pronunciations are presented in a low-key and self-confidant manner, suggesting that Abu Dhabi's destination brand is discretely superlative. Similar qualification can be given to its success. The 3.5 million tourist arrivals accommodated in 2014 is celebrated as exceeding the target of 3.1 million, but there is no strategy or apparent desire to match Dubai's more than 11 million visitors. A continual parade of major global celebrities and events provides ongoing evidence of Abu Dhabi's success as an international tourist destination, as do nine consecutive World Travel Awards for the carrier Etihad as the Middle East's leading airline. The taken-for-granted and discrete character of such patronages and accolades characterise the emirate as subtly successful.

Further differentiation from Dubai focuses on sustainability. In tandem with the emphasis on tradition and culture, widespread efforts are underway to maintain the cultural and environmental integrity of Abu Dhabi. One indication of the latter is the hosting of Abu Dhabi Sustainability Week - an annual 'global forum that unites thought leaders, policy makers and investors to address the challenges of renewable energy and sustainable development' (WFES, 2015) - and which can be seen both as an ironic counterpoint to Abu Dhabi's prolific oil output and also a logical response to the eventual depletion of that resource. A major indication of the emirate's purported commitment is the ongoing development of Masdar City, a carbon-neutral, high-technology satellite city (and tourist attraction) intended to position Abu Dhabi as a global supplier and role model of green technological innovation (Reiche, 2010). As of 2012, 13.2\% of Abu Dhabi had been designated as protected areas, one outcome of which has been the successful reintroduction of species such as the Arabian Oryx which had become extirpated in the wild (Environment Agency - Abu Dhabi, 2015). Having the financial and 
land resources to pursue and realise such ambitious initiatives, we propose that being seriously sustainable is an important dimension of the destination brand, although accusations of worker abuse, as in Dubai, have attended the construction of signature projects such as the Guggenheim Museum and Louvre extension (Human Rights Watch, 2015).

The strategic element in the Abu Dhabi destination brand is largely induced, in contrast to the spontaneous or 'organic' development of Dubai as a trading hub and crossroads. Abu Dhabi possesses a similarly advantageous location, but because of its conservative tendencies did not capitalise on this situational asset until recently. Embodying this new approach is Abu Dhabi International Airport, which has emulated Dubai International Airport's development as a major transit hub, and the local carrier Etihad, $70 \%$ of whose traffic consists of stopovers transiting through Abu Dhabi (Murel \& O'Connell, 2011). As with the overall stayover visitation patterns, Abu Dhabi's airport handled 'only' 16.5 million passengers in 2013 (Abu Dhabi Airport, 2015), compared with about 75 million for Dubai. Having to be both proactive with regard to anticipated transit trends as well as reactive to developments at Dubai's airport, Abu Dhabi can be described as being strategically strategic, that is, engaging in careful planning to optimise the benefits from its favourable location. This is evident in the long-term strategic plan (Abu Dhabi, 2008). As in Dubai, new terminal designs and renovations are intended to serve as quasi-destinations, using destination-themed attractions for enticing stopovers to return in future as overnight visitors (Carrington, 2013).

Arguably, the culminating dimension of Abu Dhabi's destination brand is stability, a positive consequence of what we deem to be its slower, more deliberate and more understated brand proposition. This captures assurances of visitor safety, predictably satisfying experiences, slower and more considered growth, etc., all backed by the emirate's deep financial resources and conservative proclivities. As such, and beyond tourism, being reliably stable situates Abu Dhabi as a safe place to invest or reside for the long term, leading to patterns of development that reinforce and complement a strong tourism sector. A notable feature of tourism in Abu Dhabi that underscores several of the qualified $6 \mathrm{~S}$ parameters is the high level of domestic patronage, wherein $25 \%$ of all hotel-nights in 2013 were accounted for by residents of the UAE (Abu Dhabi Statistics Centre, 2015). This indicates a highly stable localised market segment which serves to counterbalance the ever-increasing number of transit passengers, and also a market that is more sustainable due to its spatial proximity and cultural conformity.

\section{Discussion and Conclusion}

Both Elsheshtawy (2010) and Steiner (2010) ascribe to the Middle East a trend of 'Dubaisation' wherein major regional cities are seeking to gain 
brand visibility and sustained economic development by emulating the precedent-setting 'hyper-real' urban forms of Dubai. We regard such characterisations, however, as superficial and misleading. It is true according to Ponzini (2011) that Abu Dhabi (as well as Doha and Bahrain elsewhere in the Gulf region) is using signature architecture and large-scale construction for 'global marketing purposes', but these are intended to positively differentiate the emirate from the 'mere business' of Dubai (p. 252). We propose that this differentiation can be captured in a qualified and re-sequenced version of Dubai's $6 \mathrm{~S}$ model, and furthermore that this model can be encapsulated in aspirations to be sublime - an implied counterpoint to superficial Dubai. Abu Dhabi does not want to be, and probably never will be, another Dubai, even though the two emirates - the sublime and the superficial - are becoming increasingly interdependent (Bloch, 2010). Indeed, Bloch points out the fierce competition for primacy by different attractions, structures and development companies within Dubai, perhaps a more significant rivalry than the inter-emirate one given the common frame of brand reference and implicit encouragement to outcompete each other for attention and iconic worthiness. Competition and substitutability among sub-brands within a supposedly unified common destination brand is a topic that merits further investigation, especially where it involves such rival superlatives. Does such internecine warfare, for example, inevitably undermine the umbrella brand, or can it actually strengthen the latter if it yields publicity and imagery that invokes innovation and creativity among friendly rivals?

This is not to say that competition between the two emirates is unknown. To give one infamous example, the Burj Khalifa (the world's tallest building as of 2015) was originally named the Burj Dubai in a blatant show of parochialism and demonstration of Dubai's purported regional hegemony (Elsheshtawy, 2010). The current name, conferred in the wake of the Abu Dhabi bailout, honours Sheikh Khalifa Bin Zayed Al Nahyan, the thenruler of Abu Dhabi and President of the UAE, in what may be interpreted as a counter-demonstration of Abu Dhabi's hegemony and a humiliation for Dubai (Fattah \& Daya, 2010). Another illustration is the futuristic Masdar City development (see above), which Reiche (2010) contends (on the basis of conversations with local informants) was motivated at least in part by a desire to undermine alleged efforts by Dubai to project a more environmentally friendly image than Abu Dhabi. Such indications of rivalry could become more frequent and more amplified if the status quo of excess demand over supply is inverted. It is assumed, for example, that the anticipated passenger capacity of 340 million for the airports of Dubai, Abu Dhabi and Doha by 2020 (up from 92 million in 2010) will be satisfied by predictions of rapidly growing and high per capita wealth resident populations, as well as continued growth in interregional Asia-Europe travel (Murel \& O'Connell, 2011). If such predictions prove overly optimistic, then fierce and probably 
acrimonious competition for passenger traffic between these highly capitalised showcase airports will be likely.

Dubai and Abu Dhabi, accordingly, will both continue to develop as major regional oases of stayover and stopover tourism, though with Dubai likely maintaining substantially higher volumes of visitation and transit. To address the question posed at the beginning of this chapter the latter will therefore both retain its status as The Global Arab City and also function as such within a constellation of Global Arab Cities that includes Abu Dhabi, Doha and Bahrain. We do not endorse either Dubai or Abu Dhabi as a preferred model of regional tourism development. Rather, we situate them on opposite ends of a 'superficial-to-sublime' continuum and recommend that other aspirants, as warranted by their own idiosyncratic circumstances and objectives, use dialectical logic to identify an appropriate synthesis. Moreover, as advocated by Weaver (2014), we recommend that a similarly resolutionbased dialectical approach be employed in all cases to achieve 'enlightened mass tourism', or mass tourism that is positively qualified by the injection of 'alternative tourism' impulses such as ethics and compassion. Concurrently, aspirants in the Middle East should appreciate and try to emulate the success of Abu Dhabi and Dubai in achieving local stability and prosperity despite chronically unstable regional circumstances.

The degree to which the entities in this evolving regional destinationconstellation function more or less independently, undermine one another or foster symbiotic relationships is also worthy of further investigation. Although there has never been any tourism-related planning or coordination even within the UAE (Sharpley, 2002), it would be prudent for these four entities, and potentially others, to establish formal mechanisms (for example, a 'Council of Gulf Tourism Cities') to foster symbiosis by coordinating their disparate but similar tourism strategies and sharing intelligence. This would better ensure that all can continue to thrive in their capacity as important and proximate centres of tourism with strong and positive destination brand propositions. Beyond unexpected long-term supply-demand disequilibrium, this proposed Council would also need to assess more immediate risks to its constituent brands, such as 'Arab Spring' diffusion possibilities, the expansion of the self-styled caliphate, and tensions between Saudi Arabia and Iran.

The issue of an emergent post-sanctions Iran in 2016 poses further implications and research possibilities. The geopolitical reality is that Shi'ite Iran has jurisdiction over the northern part of the Persian (or Arabian) Gulf. Two islands, Kish and Qeshm, are already accommodating substantial and mostly domestic leisure tourist visitation. Dubai-like intensification here and potentially in other Iranian Gulf destinations, with stronger international participation, is not an outlandish proposition given the free trade zone status already conferred on these islands (Hakimian, 2013). We propose, in anticipation, that the UAE and Iran jointly sponsor international conferences and 
ongoing dialogue with the goal of mobilising tourism as a vehicle for regional and world peace. Such a strategy could anchor a broader 'Gulf of Peace' regional destination branding proposition capable also of reinforcing, symbiotically, its component destination brands on both sides of the Gulf.

Of course, there is no guarantee of success in any of these actual or proposed strategies, and the experience of Beirut, a quasi-European destination celebrated until the 1970s as the 'Paris of the Middle East' (Rowbotham, 2010) is a regional reminder of how ascent and hubris, in absence of resilience and cooperation, can be superseded by descent and humiliation. A concluding issue is that tourism cannot be engaged in isolation from the many nontourism actors and sectors, such as finance, oil and gas, construction, education and high technology, which develop in these destinations concurrently and make important contributions to the destination and overall brand. This reflects the utility of a broader 'mobilities' paradigm that implicates stayovers and stopovers but also temporary and permanent migrants, and other exchanges of goods and services often excluded from tourism discourses (Hannam et al., 2006). Fluctuating fossil fuel prices and declining inventories are a related consideration. Affiliated revenue has allowed both Dubai and Abu Dhabi to pursue grand tourism visions, in part in anticipation of fossil fuel depletion and the subsequent need for economic diversification. Those same well-articulated tourism sectors, in tandem with the vast UAE sovereign funds, will help to compensate for shorter-term price fluctuations, so that the stability of the proposed $6 \mathrm{~S}$ models should not be unduly affected.

\section{References}

Abdelal, R. (2009) Sovereign wealth in Abu Dhabi. Geopolitics 14 (2), 317-327.

Abu Dhabi (2008) The Abu Dhabi Economic Vision 2030. See https://www.ecouncil.ae/ PublicationsEn/economic-vision-2030-full-versionEn.pdf (accessed 20 May 2015).

Abu Dhabi Airport (2015) Introduction. See http://www.abudhabiairport.ae/english/airport-information/about-abu-dhabi-airport/introduction.aspx (accessed 19 May 2015).

Abu Dhabi Statistics Centre (2015) Hotels Establishments, Abu Dhabi Emirates. See http://www.scad.ae/en/statistics/Pages/Statistics.aspx?ThemeID=3\&TopicID =13\& SubTopicID=49\&PublicationID=448 (accessed 23 September 2015).

Ali, S. (2010) Dubai: Gilded Cage. Hartford: Yale University Press.

Bagaeen, S. (2007) Brand Dubai: The instant city; or the instantly recognizable city. International Planuing Studies 12 (2), 173-197.

Balakrishnan, M. (2008) Dubai - a star in the East. Journal of Place Management and Developmeni 1 (1), 62-91.

Bassens, D. (2010) The making and breaking of Dubai: The end of a city-state? Political Geography 29 (6), 299-301.

Blain, C., Levy, S. and Ritchie, J.R.B. (2005) Destination branding: Insights and practices from destination management organizations. Journal of Travel Research 43 (4), 328-338.

Bloch, R. (2010) Dubai's long goodbye. Intermational Journal of Urban and Regional Research $34(4), 943-951$. 
Carrington, D. (2013) My airport's bigger than yours: Middle East's big aviation ambitions. CNN. 2 September. See http://edition.cnn.com/2013/08/30/travel/myairports-bigger-than-yours/ (accessed 19 May 2015).

Davidson, C. (2007) The emirates of Abu Dhabi and Dubai: Contrasting roles in the international system. Asian Affairs 38 (1), 33-48.

Dubai Airports (2015) Dubai airports review 2015. See http://www.dubaiairportsreview. com/wp-content/uploads/2016/05/Dubai-Airports-Yearbook-Downloadable-2015. pdf (accessed 31 August 2016).

Dubai Tourism (2015) Tourism Vision 2020. See http://www.visitdubai.com/en/depart ment-of-tourism new/about-dtcm/tourism-vision-2020

Elsheshtawy, Y. (2010) Dubai: Behind an Urbant Spectacle. London: Routledge.

Environment Agency - Abu Dhabi (2015) Protected Areas. See http://www.ead.ae/knowyour-environment/biodiversity/protected-areas/

Expo 2020 (2016) An unforgettable experience. See http://expo2020dubai.ae/

Fakeye, P. and Crompton, J. (1991) Image differences between prospective, first-time, and repeat visitors to the lower Rio Grande Valley. Journal of Travel Research 30 (2), 10-16.

Fattah, Z. and Daya, A. (2010) Dubai tower's name reflects U.A.E. shift. Bloomberg Business. 5 January. See http://www.businessweek.com/globalbiz/content/jan2010/ gb2010015 736675.htm (accessed 19 May 2015).

Government of Dubai (2015) Dubai Statics Center: Tourism. See https://www.dsc.gov. ae/en-us/Themes/Pages/Tourism.aspx? Theme $=30$ (accessed 23 September 2015).

Hakimian, H. (2013) Iran's free trade zones: Back doors to the international economy? In P. Alizadeh and H. Hakimian (eds) (pp. 102-123). Iran and the Global Econonny: Petro Populism, Islam and Economic Sanctions. London: Routledge.

Hannam, K., Sheller, M. and Urry, J. (2006) Editorial: Mobilities, immobilities and moorings. Mobilities 1 (1), 1-22.

Hazbun, W. (2006) Explaining the Arab Middle East tourism paradox. The Arab World Geographer 9 (3), 201-214.

Henderson, J. (2007) Destination development: Singapore and Dubai compared. Journal of Travel \& Tourism Marketing 20 (3/4), 33-45.

Human Rights Watch (2015) UAE: Abuses at NYU, Louvre, Guggenheim project. 10 February. See http://www.hrw.org/news/2015/02/10/urae-abuses-nyu-louvre-guggenheim-project (accessed 19 May 2015).

Keller, K. (1993) Conceptualizing, measuring, and managing customer-based brand equity. Joumal of Marketing 57 (1), 1-22.

Kim, W. and Mauborgne, R. (2009) How strategy shapes structure. Harvard Business Review 87 (9), 72-80.

Lawler, E. (2005) Creating high performance organizations. Asia Pacific Journal of Human Resources 43 (1), 10-17.

MacCannell, D. (1976) The Tourist: A New Theory of the Leisure Class. New York: Schocken Books.

MECSD (Middle East Centre for Sustainable Development) (2015). Welcome to MECSD. See http://www.mecsd.com/ (accessed 20 May 2015).

Morgan, N., Pritchard, A and Piggott, R. (2002) New Zealand, 100\% Pure. The creation of a powerful niche destination brand. Brand Management 9, 335-354.

Murel, M. and O'Connell, J. (2011) Potential for Abu Dhabi, Doha and Dubai Airports to reach their traffic objectives. Research in Transportation Business \& Managensent 1 (1), $36-46$.

Ponzini, D. (2011) Large scale development projects and star architecture in the absence of democratic politics: The case of Abu Dhabi, U.AE. Cities 28 (3), 251-259.

Reiche, D. (2010) Renewable energy policies in the Gulf countries: A case study of the carbon-neutral 'Masdar City' in Abu Dhabi. Energy Policy 38 (1), 378-382. 
Rowbotham, J. (2010) 'Sand and foam': The changing identity of Lebanese tourism. Journal of Tourism History 2 (1), 39-53.

Sambidge, A. (2012) Abu Dhabi foreign assets worth at least $\$ 300 \mathrm{bn}$. Arabian Business. com. See http://www.arabianbusiness.com/abu-dhabi-foreign-assets-worth-at-least30 bn-473029.html (accessed 17 September 2015).

Sharpley, R. (2002) The challenges of economic diversification through tourism: The case of Abu Dhabi. International Journal of Tourism Research 4 (3), 221-235.

Skift (2015) Abu Dhabi hotel data indicates robust tourism growth in 2013. See http:// skift.com/2013/07/10/abu-dhabi-hotels-on-track-for-record-year-in-2013/ (accessed 24 September 2015).

Steiner, C. (2010) From heritage to hyper-reality? Tourism destination development in the Middle East between Petra and the Palm. Journal of Tourism and Cultural Change 8 (4), 240-253.

Stephenson, M. (2014) Tourism, development and 'destination Dubai': Cultural dilemmas and future challenges. Current Issues in Tourism 17 (8), 723-738.

Stephenson, M. and Ali-Knight, J. (2010) Dubai's tourism industry and its societal impact: Social implications and sustainable challenges. Journal of Tourism and Cultural Change 8 (4), 278-292.

Tang, C. (2015) Exploring the Potential of Hub Airports and Airlines to Convert Stopover Passengers into Stayover Visitors: Evidence from Singapore. Unpublished PhD thesis, Griffith University, Gold Coast, Australia.

Visit Dubai (2015) Discover all that's possible. See http://www.visitdubai.com/en (accessed 23 September 2015).

Weaver, D. (2014) Asymmetrical dialectics of sustainable tourism: Toward enlightened mass touxism. Journal of Travel Research 53 (2), 131-140.

Wehrey, F., Karasik, T., Nader, A., Ghez, J., Hansell, L. and Guffey, R. (2009) SaudiIranian Relations Since the Fall of Saddam: Rivalry, Cooperation, and Implications for U.S. Policy. Santa Monica, CA: RAND Corporation. See http://www.dtic.mil/ dtic/tr/fulltext/u2/a495436.pdf (accessed 17 September 2015).

WFES (World Future Energy Summit) (2015) Abu Dhabi Sustainability Week. See http:// www.world futureenergysummit.com/portal/about-wfes/overview/abu-dhabisustainability-week.aspx (accessed 19 May 2015).

World eBook Library (2015) Sheikh Zayed Mosque. See http://ebook.worldlibrary.net/ Article.aspx?Title=Sheikh_Zayed_Mosque (accessed 17 September 2015). 